\title{
Screening of a Natural Feed Additive Having Anti-viral Activity against Influenza A/H5N1
}

\author{
Jang-Hyun Lee, Su Min Kwon, Sang Heui Seo', Young-Seo Park², Young-Bong Kim, \\ Soo-Ki Kim, and Hyun-Dong Paik* \\ Division of Animal Life Science, Konkuk University, Seoul 143-701, Korea \\ ${ }^{I}$ College of Veterinary Medicine, Chungnam National University, Daejeon 305-764, Korea \\ ${ }^{2}$ Department of Food Science and Biotechnology, Kyungwon University, Seongnam, Gyonggi 461-701, Korea
}

\section{안전한 닭고기 생산을 위한 고병원성 조류인플루엔자 A/H5N1에 항바이러스 효과를 가진 천연 사료첨가제의 탐색}

\author{
이장현 · 권수민 · 서상희 ${ }^{1} \cdot$ 박영서 $^{2}$ · 김영봉 · 김수기 · 백현동* \\ 건국대학교 동물생명과학부, ${ }^{1}$ 충남대학교 수의과대학, ${ }^{2}$ 경원대학교 식품생물공학과
}

\begin{abstract}
To search for anit-H5N1 influenza virus agent, the anti-viral activity of methanol and aqueous extracts from thirty medicinal plants were examined in this study. The plant material $(30 \mathrm{~g})$ was extracted with methanol $(300 \mathrm{~mL})$ for $24 \mathrm{hr}$ at room temperature. Methanol extracts were filtered and evaporated, then freeze-dried. Aqueous extracts were prepared with dried plant material $(30 \mathrm{~g})$ and hot distilled water $(300 \mathrm{~mL})$. After $3 \mathrm{hr}$, the aqueous extracts were filtered and evaporated, then lyophilized. Extracts prepared from different plants were tested the antiviral activity against influenza viruses [A/Vietnam/ 1194/04 (H5N1)-NIBRG-14] using the hemagglutination (HA) assay. Among the test plants, Asarum sieboldii was found to be a potent inhibitor of $\mathrm{H} 5 \mathrm{~N} 1$ influenza virus in MDCK cell culture. Virus titers were $7 \mathrm{log}$, whereas with methanol extract of Asarum sieboldii for $48 \mathrm{hr}$ titers were $3 \mathrm{log}$, indicating that methanol extract of Asarum sieboldii inhibited the H5N 1 influenza viruses from the infected cells.
\end{abstract}

Key words : influenza A/H5N1, highly pathogenic avian influenza, feed additive, anti-viral activity, Asarum sieboldii

\section{Introduction}

Avian influenza A subtype H5N1 virus, with their ability to cause fatal infections and pathogenesis in humans has recently appeared in Asian countries (De Jong and Hien, 2006). The subsequent re-emergence of human $\mathrm{H} 5 \mathrm{~N} 1$ disease with high fatality rates has been reported in southern China (Shortridge et al., 1998; Yan et al., 2007), Thailand (Amonsin et al., 2006), Indonesia, and Vietnam (Smith et al., 2006). Currently, some drugs are available with antiviral activity against influenza viruses: amantadine, remantadine, zanamivir, and oseltamivir (De Jong and Hien, 2006).

*Corresponding author : Hyun-Dong Paik, Division of Animal Life Science, Konkuk University, Seoul 143-701, Korea. Tel.: 82-2-2049-6011, Fax: 82-2-455-1044, E-mail: hdpaik@konkuk. ac.kr
But these synthetic drugs have side effects and limitations. Also, it has been reported that drug-resistant $\mathrm{H} 5 \mathrm{~N} 1$ influenza virus was isolated from Vietnam, and China (Le et al., 2005; He et al., 2008). The influenza virus (A/Hanoi/30408/2005 (H5N1)) isolated from a Vietnamese girl in 2005 was an oseltamivir-resistant virus (Le et al., 2005), and $83.3 \%$ of influenza viruses isolated from chicken in Hebei Province of Northern China from 2001 to 2005 were resistant to amantadine (He et al., 2008). Therefore, much attention has been placed into searching for natural substances having antiinfluenza effects (Mukhtar et al., 2008).

The efforts to search for influenza virus natural inhibitors are very ancient. In particular herbal drugs as anti-influenza agents have been mainly used in East Asia, China, Korea, and Japan (Wang et al., 2006). The recent studies suggest that several natural substances isolated from several plants have anti-influenza activity both in vitro and in vivo. 
Polyphenolic compound catechins ((-)-epigallocatechin gallate, (-)-epicatechin gallate and (-)-epigallocatechin) from Camellia sinensis (green tea) inhibit influenza virus replication in MDCK cell culture and potentially direct virucidal effect (Song et al., 2005). Methanol extracts from Korean medicinal plants, Ephedra sinica (Eupedraceae), Areca catechu (Palmae), Paeonia lactiflora (Ranunculaceae), and Magnolia obovata (Magnoliaceae), have inhibitory activity against the influenza virus (A/Taiwan/1/86 (HIN1)) (Park, 2003). A polyphenol rich extract from Cistus incanus PANDALIS has anti-influenza virus activity against the human influenza isolate (A/Thailand/1(KAN-1)/2004 (H5N1)) (Ehrhardt et al., 2007). It also has reported that the extract of Cochinchina momordica seed as an adjuvant has potential to improve the efficacy of influenza vaccination (H5N1) in chickens (Rajput et al., 2007).

In this study, we aimed to test thirty oriental medicinal plants with putative anti-viral activity against influenza $\mathrm{A}$ virus subtype $\mathrm{H} 5 \mathrm{~N} 1$ in MDCK cell cultures.

\section{Materials and Methods}

\section{Viruses and cells}

H5N1 (A/Vietnam/1194/04 (H5N1)-NIBRG-14) influenza viruses were propagated in the allantoic cavities of 11-d-old embryonated chicken eggs in approved biosafety level-3 (BL-3) containment facility. MDCK (Madin-Darby canine kidney) cells were cultivated in MEM supplemented with $10 \%$ FBS. The procedures for cell culture and virus titration were performed as described elsewhere (Seo et al., 2004).

\section{Preparation of plant extracts}

Medicinal plants were selected from Korean medicine book describing traditional medicines. The scientific names of plants are shown in Table 1.

Extract of medicinal plants was prepared according to the standard methods with minor modification as previously reported (Kim et al., 2007; Shin et al., 2008). Briefly, the air-dried and finely ground samples were extracted by using the method as described below. Plants ( $30 \mathrm{~g}$ ) were extracted

Table 1. Medicinal plant extracts used in this study

\begin{tabular}{|c|c|}
\hline Botanical name (family) & Part used \\
\hline Petasites japonicus (Asteraceae) & Flower \\
\hline Trichosanthes kirilowii Maxim. (Cucurbitaceae) & Fruit \\
\hline Platycodon grandiflorum (Campanulaceae) & Root \\
\hline Ephedra sinica (Ephedraceae) & Aerial \\
\hline Liriope platyphylla (Liliaceae) & Root \\
\hline Brassica juncea Czern. et Coss (Cruciferae) & Seed \\
\hline Ginkgo biloba L. (Ginkgoaceae) & Fruit \\
\hline Stemona japonica Miq. (Stemonaceae) & Root \\
\hline Eriobotrya japonca (Thumb.) Lindl. (Rosaceae) & Leaf \\
\hline Adenophora triphylla var japonica Hara (Campanulaceae) & Root \\
\hline Morus alba L. (Moraceae) & Bark \\
\hline Asarum sieboldii Miq. (Aristolchiaceae) & Root \\
\hline Perilla frutescens var acuta Kubo (Labiatae) & Leaf \\
\hline Schizandra chinensis Baill. (Magnoliaceae) & Fruit \\
\hline Polygala japonica Houtt. (Polygalaceae) & Root \\
\hline Aster tataricus L. f. (Compositae) & Root \\
\hline Peucedanum decursivum Maxim. (Umbelliferae) & Root \\
\hline Fraxinus rhynchophylla Hance (Oleaceae) & Bark \\
\hline Fritillaria thunbergii Miq. (Liliaceae) & Stem \\
\hline Prunus armeniaca var. ansu Maxim. (Rosaceae) & Seed \\
\hline Codonopsis pilosula (Franch) Nannf. (Campanulaceae) & Root \\
\hline Polygonum multiflorum Thumb. ex Murray (Polygonaceae) & Root \\
\hline Atractylodes macrocephala Koidzumi (Compositae) & Root \\
\hline Astragalus complanatus $\mathrm{R}$. Br. (Leguminosae) & Seed \\
\hline Cornus officinalis Siebold \& Zucc. (Cornaceae) & Fruit \\
\hline Dioscorea japonica Thumb. (Dioscoreaceae) & Root \\
\hline Nelumbo nucifera Gaertn. (Nympheaceae) & Seed \\
\hline Acanthopanax sessiliflonus var parviceps Rehder (Araliaceae) & Bark \\
\hline Achyranthes japonica Nakai (Amarnthaceae) & Root \\
\hline Cistanche deserticola Y. C. Ma (Orobanchaceae) & Root \\
\hline
\end{tabular}




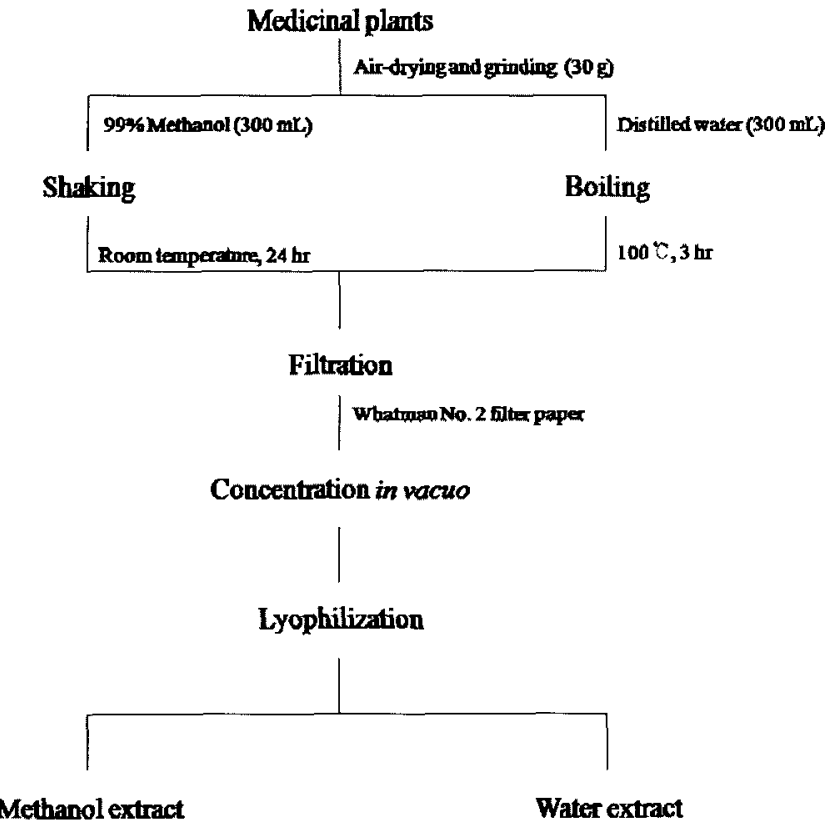

Fig. 1. Procedure to prepare extracts from medicinal plants in this study. with $300 \mathrm{~mL}$ of methanol (99\%) for $24 \mathrm{hr}$ at room temperature on a rotating shaker $(180 \mathrm{rpm})$. Crude aqueous extracts were also prepared with $30 \mathrm{~g}$ of powdered plant material. Each sample was added to $300 \mathrm{~mL}$ of distilled water in a glass flask, boiled for $3 \mathrm{hr}$. After filtration through Whatman No. 2 filter paper, the filtrate was concentrated under reduced pressure and lyophilized, then stored at $4^{\circ} \mathrm{C}$ (Fig. 1).

\section{Anti-viral activity assay}

The anti-viral activity of extracts was determined as described below. Briefly, confluent monolayers of MDCK cells on the 6-well plates were infected with $100 \mathrm{~mL}$ of 100 $\mathrm{TCID}_{50} / \mathrm{mL}$ of $\mathrm{H} 5 \mathrm{~N} 1$ viruses. One hr later, plant extracts in MEM media (3 $\mathrm{mL}$ ) at a non-toxic concentration were added to MDCK cells in well of 6-well plates, and cells were incubated for $48 \mathrm{hr}$. After this incubation period, virus titers were determined by hemagglutination (HA) assays. The anti-viral activity was defined as a $4 \log$ reduction.

Table 2. Inhibitory activity of medicinal plants on influenza virus A/H5N1

\begin{tabular}{|c|c|c|}
\hline Botanical name (family) & Methanol extract & Water extract \\
\hline Petasites japonicus (Asteraceae) & - & - \\
\hline Trichosanthes kirilowii Maxim. (Cucurbitaceae) & - & - \\
\hline Platycodon grandiflorum (Campanulaceae) & - & - \\
\hline Ephedra sinica (Ephedraceae) & - & - \\
\hline Liriope platyphylla (Liliaceae) & - & - \\
\hline Brassica juncea Czern. et Coss (Cruciferae) & - & - \\
\hline Ginkgo biloba L. (Ginkgoaceae) & - & - \\
\hline Stemona japonica Miq. (Stemonaceae) & - & - \\
\hline Eriobotrya japonca (Thumb.) Lindl. (Rosaceae) & - & - \\
\hline Adenophora triphylla var japonica Hara (Campanulaceae) & - & - \\
\hline Morus alba L. (Moraceae) & - & - \\
\hline Asarum sieboldii Miq. (Aristolchiaceae) & + & - \\
\hline Perilla frutescens var. acuta Kubo (Labiatae) & - & - \\
\hline Schizandra chinensis Baill. (Magnoliaceae) & - & - \\
\hline Polygala japonica Houtt. (Polygalaceae) & - & - \\
\hline Aster tataricus L. f. (Compositae) & - & - \\
\hline Peucedanum decursivum Maxim. (Umbelliferae) & - & - \\
\hline Fraxinus rhynchophylla Hance (Oleaceae) & - & - \\
\hline Fritillaria thunbergii Miq. (Liliaceae) & - & - \\
\hline Prunus armeniaca var ansu Maxim. (Rosaceae) & - & - \\
\hline Codonopsis pilosula (Franch) Nannf. (Campanulaceae) & - & - \\
\hline Polygonum multiflorum Thumb. ex Murray (Polygonaceae) & - & - \\
\hline Atractylodes macrocephala Koidzumi (Compositae) & - & - \\
\hline Astragalus complanatus $\mathrm{R} . \mathrm{Br}$. (Leguminosae) & - & - \\
\hline Cornus officinalis Siebold \& Zucc. (Cornaceae) & - & - \\
\hline Dioscorea japonica Thumb. (Dioscoreaceae) & - & - \\
\hline Nelumbo nucifera Gaertn. (Nympheaceae) & - & - \\
\hline Acanthopanax sessiliflorus var. parviceps Rehder (Araliaceae) & - & - \\
\hline Achyranthes japonica Nakai (Amarnthaceae) & - & - \\
\hline Cistanche deserticola Y. C. Ma (Orobanchaceae) & - & - \\
\hline
\end{tabular}

+: detected, -: not detected. 


\section{Results and Discussion}

The anti-viral activity of oriental medicinal plants against highly pathogenic avian influenza virus $\mathrm{H} 5 \mathrm{~N} 1$ was examined in vitro.

Out of the 30 samples tested, only the methanol extract of Asarum sieboldii was shown to inhibit the H5N1 (A/Vietnam/1194/04 (H5N1)-NIBRG-14) influenza virus (Table 2). Virus titers were $2^{7} \mathrm{HA}$ unit in case of sample-free, whereas with methanol extract of Asarum sieboldii virus titer was reduced to $3 \log$. Asarum sieboldii (Fig. 2), a perennial herb in the family Aristolochiaceae, is mainly distributed in Korea and China. It has been traditionally used as a medicine in cold and pains. It has been reported that its water extract have liver-protective effect (Cho and Yoon, 1999) and a propiophenone derivative from its rhizome inhibits harmful microorganisms (Lee et al., 2005; Yu et al., 2006). Kim et al. has also reported that Asarum sieboldii was shown to have a role of histamine pathways, and it has been used to treat histamine-related diseases traditionally (2003). This is the first report describing the anti-viral activity of Asarum sieboldii against high pathogenic avian influenza $\mathrm{A}$ H5N1.

Although further studies need to identify the bioactive substance of Asarum sieboldii, this early study suggests that an oriental traditional medicinal plant as a natural feed additive have a potential to be used in treatment of poultry diseases caused by high pathogenic avian influenza A H5N1.

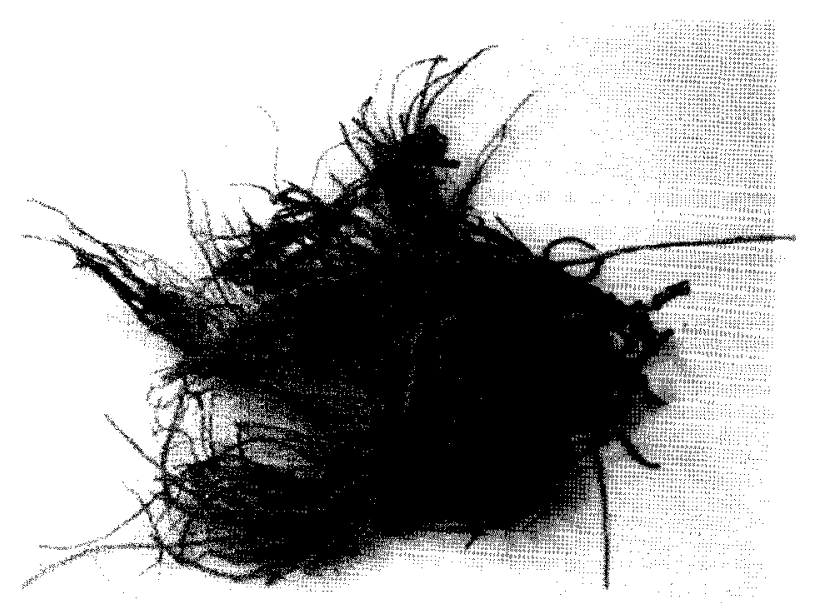

Fig. 2. Root of Asarum sieboldii Miq. (Aristolchiaceae).

\section{Acknowledgments}

This work was supported by a grant (Code $\$ 200702157$ ) from Biogreen 21 program, Rural Development Administration and the Brain Korea 21 Project, Korea.

\section{References}

1. Amonsin, A., Chutinimitkul, S., Pariyothorn, N., Songserm, T, Damrongwantanapokin, S., Puranaveja, S., Jam-on, R., Sae-Heng, N., Payungporn, S., Theamboonlers, A., Chaisingh, A. Tantilertcharoen, R., Suradhat, S., Thanawongnuwech, R., and Poovorawan, Y. (2006) Genetic characterization of influenza A viruses (H5N1) isolated from 3rd wave of Thailand AI outbreaks. Virus Res. 122, 194-199.

2. Cho, E. and Yoon, S. (1999) Protective effect of Asiasari Radix on rat liver. J. Korean Soc. Hyg. Sci. 5, 85-91.

3. De Jong, M. D., and Hien, T. T. (2006) Avian influenza A (H5N1). J. Clin. Virol. 35, 2-13.

4. Ehrhardt, C., Hrincius, E. R., Korte, V., Mazur, I., Droebner, K., Poetter, A., Dreschers, S., Schmolke, M., Planz, O., and Ludwig, S. (2007) A polyphenol rich plant extract, CYSTUS052, exerts anti influenza virus activity in cell culture without toxic side effects or the tendency to induce viral resistance. Antiviral Res. 76, 38-47.

5. He, G., Qiao, J., Dong, C., He, C., Zhao, L., and Tian, Y. (2008) Amantadine-resistance among $\mathrm{H} 5 \mathrm{~N} 1$ avian influenza viruses isolated in Northern China. Antiviral Res. 77, 72-76.

6. Kim, H., Bang, C., Choi, Y., and Lee, J. (2007) Antioxidant and antiproliferative activities of methanol extracts from leafy vegetables consumed in Korea. Food Sci. Biotechnol. 16, 802-806.

7. Kim, S., Zhang, C. G., and Lim, J. T. (2003) Mechanism of anti-nociceptive effects of Asarum sieboldii Miq. Radix: potential role of bradykinin, histamine and opioid receptormediated pathways. J. Ethnopharmacol 88, 5-9.

8. Le, Q. M., Kiso, M., Someya, K., Sakai, Y. T., Nguyen, T. H., Nguyen, K. H. L., Pham, N. D., Ngyen, H. H., Yamada S., Muramoto, Y., Horimoto, T., Takada, A., Goto, H., Suzuki, T., Suzuki, Y., and Kawaoka Y. (2005) Isolation of drugresistant $\mathrm{H} 5 \mathrm{~N} 1$ virus. Nature 437, 1108.

9. Lee, J. Y., Moon, S. S., and Hwang, B. K. (2005) Isolation and antifungal activity of kakuol, a propiophenone derivative from Asarum sieboldii rhizome. Pest Manag. Sci. 61, 821825 .

10. Mukhtar, M., Arshad, M., Ahmad, M., Pomerantz, R. J., Wigdahl, B., and Parveen, Z. (2008) Antiviral potentials of medicinal plants. Virus Res. 131, 111-120.

11. Park. K. J. (2003) Evaluation of in vitro antiviral activity in methanol extracts against influenza virus type A from Korean medicinal plants, Phytother. Res. 17, 1059-1063.

12. Rajput, Z. I., Xiao, C., Hu, S., Arijo, A. G., and Soomro, N. M. (2007) Improvement of the efficacy of influenza vaccination (H5N1) in chicken by using extract of Cochinchina momordica seed (ECMS). J. Zhejiang Univ. Sci. B 8, 331337.

13. Seo, S. H., Hoffmann, E., and Webster, R. G. (2004) The NS1 gene of $\mathrm{H} 5 \mathrm{~N} 1$ influenza viruses circumvents the host antiviral cytokine responses. Virus Res. 103, 107-113.

14. Shin, S. R., Hong, J. Y., and Yoon, K. Y. (2008) Antioxidant properties and total phenolic contents of cherry elaeagnus (Elaeagnus multiflora Thumb.) leaf extracts. Food Sci. Bio- 
technol. 17, 608-612.

15. Shortridge, K. F., Zhou, N. N., Guan, Y., Gao, P., Ito, T., Kawaoka, Y., Kodihalli, S., Krauss, S., Markwell, D., Murti, K. G., Norwood, M., Senne, D., Sims, L., Takada, A., and Webster, R. G. (1998) Characterization of avian H5N1 influenza viruses from poultry in Hong Kong. Virology 252, 331342.

16. Smith, G. J. D., Naipospos, T. S. P., Nguyen, T. D., De Jong, M. D., Vijaykrishna, D., Usman, T. B., Hassan, S. S., Nguyen, T. V., Dao, T. V., Bui, N. A., Leung, Y. H. C., Cheung, C. L., Rayner, J. M., Zhang, J. X., Zhang, L. J., Poon, L. L. M., Li, K. S., Nguyen, V. C., Hien, T. T., Farrar, J., Webster, R. G., Chen, H., Peiris, J. S. M., and Guan, Y. (2006) Evolution and adaptation of H5N1 influenza virus in avian and human hosts in Indonesia and Vietnam. Virology 350, 258-268.

17. Song, J., Lee, K., and Seong, B. (2005) Antiviral effect of catechins in green tea on influenza virus. Antiviral Res.68, 66-74.

18. Wang, X., Jia, W., Zhao, A., and Wang, X. (2006) Anti-influenza agents from plants and traditional Chinese medicine. Phytother. Res, 20, 335-341.

19. Yan, J., Lu, Y., Mao, H., Feng, Y., Xu, C., Shi, W., Weng, J., Li, M., Gong, L., Ge, Q., Zhou, M, Li, Z, and Chen, Y. (2007) Pathogenic and molecular characterization of the $\mathrm{H} 5 \mathrm{~N} 1$ avian influenza virus isolated from the first human case in Zhejiang province, China. Diagn. Microbiol. Infect. Dis. 58, 399-405.

20. Yu, H., Seo, S., Hur, J., Lee, H., Lee, Y., and You, Y. (2006) Asarum sieboldii extracts attenuate growth, acid production, adhesion, and water-insoluble glucan synthesis of Streptococcus mutans. J. Med. Food 9, 505-509. 